\title{
KUALITAS PELAYANAN PENETAPAN PENSIUN OTOMATIS BERBASIS LESS PAPER BAGI PEGAWAI NEGERI SIPIL DI LINGKUNGAN PEMERINTAH PROVINSI SULAWESI UTARA
}

\author{
Erni Hidayanti \\ Institut Pemerintahan Dalam Negeri (IPDN) \\ Email: erni.hidayanti@gmail.com
}

\begin{abstract}
Abstrak
Tujuan penelitian ini diarahkan untuk mengkaji kualitas pelayanan penetapan pensiun otomatis berbasis less paper bagi Pegawai Negeri Sipil di lingkungan Pemerintah Provinsi Sulawesi Utara. Penelitian ini bersifat deskriptif kualitatif dengan teknik pengumpulan data berupa wawancara, observasi dan dokumentasi. Pelaksanaan penetapan pensiun otomatis berbasis less paper bagi Pegawai Negeri Sipil di lingkungan Pemerintah Provinsi Sulawesi Utara belum berjalan dengan baik, dikarenakan belum adanya Standar Operasional Prosedur (SOP) penetapan pensiun otomatis berbasis less paper, kurangnya transparansi, lemahnya sosialisasi, lemahnya rekonsiliasai data, kurangnya SDM Aparatur, belum adanya inovasi pengembangan pemrosesan pensiun berbasis less paper, kondisi PNS yang akan memasuki batas usia pensiun belum merespon pelaksanaan penetapan pensiun otomatis berbasis less paper dengan baik. Oleh karena itu diperlukan komitmen serta keinginan yang kuat Pemerintah Provinsi Sulawesi Utara khususnya Badan Kepegawaian Daerah Provinsi Sulawesi Utara dalam membuat inovasi pengembangan penetapan pensiun otomatis berbasis less paper hingga tercipta alur layanan pensiun otomatis yang memenuhi standar kualitas pelayanan, memudahkan penerima pensiun dalam menerima surat keputusan pensiun.
\end{abstract}

Kata Kunci: Kualitas Pelayanan, Pensiun Otomatis, Perkantoran Berbasis Paperless.

\begin{abstract}
The purpose of this study was directed to examine the quality of service for determining less paper-based automatic pensions for Civil Servants in the North Sulawesi Provincial Government. This research is descriptive qualitative with data collection techniques in the form of interviews, observations and documentation. Implementation of the determination of less paper-based automatic pensions for Civil Servants in the North Sulawesi Provincial Government has not gone well, due to the absence of Standard Operating Procedures (SOP) for determining less paper-based automatic pensions, lack of transparency, weak socialization, weak data reconciliation, lack of human resources. The apparatus, there is no innovation in the development of less paper-based pension processing, the condition of civil servants who will enter the retirement age limit has not responded to the implementation of the less paper-based automatic pension determination. Therefore, it takes a strong commitment and desire from the North Sulawesi Provincial Government, especially the Regional Personnel Board of North Sulawesi Province in making innovations in developing less paper-based automatic pension determinations to create automatic pension service flows that meet service quality standards, making it easier for pension recipients to receive pension decisions.
\end{abstract}

Keywords: Automatic Pension, Service Quality, Paperless office. 


\section{A. PENDAHULUAN}

Dalam rangka mewujudkan prosedur pelayanan publik yang sederhana dan mudah melalui pemanfaatan perkembangan teknologi maka diterapkan teknologi informasi (TI) di lingkungan pemerintah, konsep yang sering dipakai adalah penerapan E-Government salah satunya prosedur pelayanan administrasi pelayanan kepegawaian yaitu Sistem Aplikasi Pelayanan Kepegawaian (SAPK) online. Dalam perkembangannya dikeluarkan Peraturan Kepala Badan Kepegawaian Negara Nomor 18 Tahun 2010 tentang Prosedur Penetapan Nomor Identitas Pegawai Negeri Sipil, Kenaikan Pangkat, Pemberhentian dan Pemberian Pensiun Pegawai Negeri Sipil,dan Perpindahan Antar Instansi Berbasis Sistem Aplikasi Pelayanan Kepegawaian On-Line (SAPK On-Line).

Untuk memperbaiki kekurangan dalam pemanfaatan aplikasi SAPK di Badan Kepegawaian Daerah, pada tahun 2016 BKN meresmikan pelaksanaan Program Kebijakan Kenaikan Pangkat Otomatis (KPO) dan Penetapan Pensiun Otomatis (PPO). Badan Kepegawaian Daerah Provinsi Sulawesi Utara sebagai perangkat daerah yang membantu kepala daerah dalam menyelenggarakan urusan pemerintahan di bidang kepegawaian selama ini telah berupaya menyelenggarakan fungsi sebagaimana tersebut di atas berdasarkan ketentuan peraturan perundang-undangan yang berlaku. Namun, berdasarkan pengalaman dan pengamatan peneliti selama bekerja sebagai PNS pada Badan Kepegawaian Daerah Provinsi Sulawesi Utara, masih ditemukan beberapa permasalahan dalam pengurusan pensiun pegawai, yang mengakibatkan pelayanan tersebut menjadi tidak optimal.

Permasalahan yang dihadapi dalam PPO Berbasis Less Paper bagi PNS di Lingkungan Pemerintah Provinsi Sulawesi Utara yaitu Seringkali ditemui beberapa persyaratan administrasi pengusulan pensiun PNS yang tidak lengkap. Pengembalian berkas usul pensiun sebagaimana tersebut di atas, mengakibatkan keterlambatan dalam proses penerbitan SK pensiun bagi pegawai yang bersangkutan. Hal ini berdampak terhadap proses pencairan gaji pokok pensiun. Apabila PNS telah mencapai batas usia pensiun yang ditetapkan oleh regulasi, maka pembayaran gaji pokok PNS tersebut akan dihentikan, dan yang bersangkutan berhak menerima gaji pensiunnya. Namun, jika berkas usul pensiunnya tidak lengkap, maka akan dikembalikan sehingga pembayaran pensiunnya pun akan ikut tertunda.

Permasalahan lainnya yaitu sering terjadi keterlambatan dalam penyampaian usulan berkas pensiun. Penyampaian usulan berkas seringkali dilakukan mendekati waktu Terhitung Masa Tanggal Pensiun. Hal ini terjadi salah satunya disebabkan adanya persepsi dari PNS yang akan memasuki usia pensiun terkait dengan kata "Otomatis". Berdasarkan fakta yang ada bahwa sikap apatis calon penerima pensiun muncul karena asumsi kata otomatis disini disalahartikan dimana PNS yang akan memasuki usia pensiun berpikiran bahwa SK pensiun akan terbit tanpa perlu lagi memasukkan kelengkapan berkas pensiun. Ekspektasi dari beberapa PNS yang akan pensiun adalah keseluruhan proses dilakukan oleh BKD tanpa adanya keterlibatan penerima pensiun itu sendiri. BKD Provinsi Sulawesi Utara telah melakukan upaya untuk mengatasi permasalahan ini dengan rutin melaksanan kegiatan setiap tahunnya berupa sosialisasi atau pembekalan terkait PPO berbasis Less Paper yang ditujukan bagi PNS yang akan memasuki usia pensiun 1 tahun sebelumnya. Akan tetapi kegiatan dimaksud hanya dapat diterapkan ke beberapa PNS tetapi tidak untuk beberapa PNS lainnya karena terkendala pada waktu sosialisasi yang mana sebagian PNS tidak bisa hadir khususnya bagi PNS Fungsional Tenaga Pendidik. Inilah yang menyebabkan kesamaan persepsi tentang PPO ini tidak berjalan dengan optimal.

Masalah lainnya adalah PPO Berbasis Less Paper hanya berlaku pada pemrosesan pensiun dari BKD Provinsi Sulawesi Utara ke Kantor Regional XI Badan Kepegawaian Negara. Sebagaimana diketahui, bahwa usulan pensiun Pegawai Negeri Sipil yang disampaikan BKD kepada BKN berdasarkan usulan dari perangkat daerah. Selama ini usulan penetapan pensiun dari perangkat daerah kepada BKD masih dilakukan secara manual, dimana 
perangkat daerah yang mengusulkan pensiun menyampaikan usulan tersebut dilengkapi dengan lampiran berkas administrasi yang cukup banyak. Kondisi tersebut menunjukkan belum terintegrasinya BKD selaku leading sector dalam proses pensiun PNS dengan perangkat daerah di lingkungan Pemerintah Provinsi Sulawesi Utara. Hal ini menyebabkan proses pensiun menjadi tidak efektif dan tidak efisien, serta tidak terpenuhinya prinsip less paper yang selalu digaungkan dalam penetapan pensiun otomatis selama ini. Terdapat beberapa PNS memasuki usia pensiun yang tidak jujur dalam pemberian data pensiun mereka khususnya data yang terkait dengan ahli waris. Beberapa data pegawai terkait dengan proses pensiun yang sering tidak dilakukan peremajaan (updating) oleh perangkat daerah. Permasalahan selanjutnya yaitu masih ditemukan adanya disharmonis data antara SAPK (Sistem Aplikasi Pelayanan Kepegawaian) Badan Kepegawaian Negara dengan SK CPNS pengusul pensiun. Permasalahan lainnya dalam proses penetapan pensiun pegawai di lingkungan Pemerintah Sulawesi Utara adalah karena kurangnya Sumber Daya Manusia yang menangani urusan pensiun dan tidak sebanding dengan jumlah pegawai yang akan memasuki masa pensiun.

Tujuan penelitian ini adalah untuk menganalisis Kualitas Pelayanan Penetapan Pensiun Otomatis Berbasis Less Paper Bagi Pegawai Negeri Sipil di Lingkungan Pemerintah Provinsi Sulawesi Utara.

\section{B. METODE PENELITIAN}

Penelitian ini dimaksudkan untuk memperoleh data dan informasi mengenai kualitas pelayanan penetapan pensiun otomatis berbasis less paper, dan menganalisis upaya yang dapat dilakukan untuk mengatasi hambatan yang ditemui. Penelitian ini menggunakan metode kualitatif dengan pengumpulan berbagai data berupa observasi, wawancara terstruktur dan studi dokumentasi. Teknik analisis data menggunakan tahapan menurut Miles dan Huberman, yaitu data reduction, data display, dan conclusion drawing/verification (Sugiyono, 2013:246).

\section{HASIL DAN PEMBAHASAN}

Kemampuan BKD Provinsi Sulawesi Utara dalam memberikan pelayanan pensiun otomatis berbasis less paper diharuskan sejalan dengan inovasi Badan Kepegawaian Negara Republik Indonesia yakni mengurangi berkas yang dilampirkan, simplifikasi proses, simplifikasi birokrasi, dan sinergi proses. Model pelaksanaan penetapan pensiun otomatis berbasis less paper dimaksudkan tentunya untuk meningkatkan pelayanan penetapan dan pemberhentian pensiun bagi Pegawai Negeri Sipil yang mencapai Batas Usia Pensiun Golongan Ruang IV/b ke bawah agar pembayaran pensiun dapat diterima tepat pada waktunya. Dimana dalam penyelenggaraan tersebut harus memiliki Standar Operasional Prosedur (SOP) yang dapat dilihat dan diakses oleh Pegawai Negeri Sipil yang akan memasuki Batas Usia Pensiun. Dalam artian lainnya bahwa merupakan kemampuan untuk memberikan pelayanan pensiun otomatis berbasis less paper secara tepat, akurat, transparan dan dapat dipercaya.

Pelaksanaan PPO Berbasis Less Paper didasari untuk mempermudah PNS dalam mengurus pensiunnya. Badan Kepegawaian Negara meresmikan pelaksanaan Penetapan Pensiun Otomatis (PPO) yang mana kebijakan tersebut sebagai bentuk komitmen BKN terhadap pelayanan kepegawaian untuk PNS yang terintegrasi alur layanan. Dengan adanya PPO berbasis less paper diharapkan dapat mempermudah mengajukan usulan pensiun, tanpa perlu mengurus beragam persyaratan dokumen (less paper), sehingga proses pengusulan dari awal hingga penetapan dapat berjalan singkat. PPO berbasis less paper dilaksanakan berdasarkan Surat Kepala Badan Kepegawaian Negara Nomor : D.26-30/V.79-5/99 Tanggal 14 Juli 2017 Perihal Penetapan Kenaikan Pengkat dan Pensiun Pegawai Negeri Sipil setelah diundangkannya Peraturan Pemerintah Nomor 11 Tahun 2017. Dalam surat tersebut dijelaskan bahwa pelaksanaan PPO berbasis less paper di seluruh instansi dilaksanakan mulai tanggal 1 Oktober 2017 dan paling lambat 1 April 2018. 
Standar Operasional Prosedur merupakan sebuah keharusan dimana kegiatan di dalam perusahaan atau organisasi akan berjalan dengan lancar karena adanya standar dan aturan sesuai tujuan yang diinginkan. Hal ini tentu wajib ditentukan sebagai petunjuk bagi pelaksana teknis atau yang pejabat yang berwenang dalam melakukan pekerjaan, yaitu adanya SOP Pemerintahan yang jelas dan terarah.

Berdasarkan data yang di dapat oleh peneliti terhadap Standar Operasional Prosedur pada Sub Bidang Pensiun PNS dan Pejabat Negara pada BKD Provinsi Sulawesi Utara didapat hanya terdapat 6 (enam) jenis pengusulan pensiun ditambah dengan 1 (satu) pengusulan Masa Persiapan Pensiun yakni terdiri dari:

a. Pengusulan Pensiun Karena Meninggal Dunia (Janda/Duda) IVb keatas;

b. Pensiun Janda Duda IV/b ke bawah;

c. Pengusulan Pensiun Atas Permintaan Sendiri;

d. Pengusulan Pensiun Pejabat Negara;

e. Pensiun BUP IVb keatas;

f. Pensiun BUP IV kebawah; dan

g. Masa Persiapan Pensiun.

Berdasarkan SOP yang ada pada Sub Bidang Pensiun PNS dan Pejabat Negara, terlihat bahwa BKD Provinsi Sulawesi Utara belum menyesuaikan SOP yang seharusnya berdasarkan Pasal 238 Peraturan Pemerintah Nomor 11 Tahun 2017 tentang Manajemen Pegawai Negeri Sipil. Mengacu pada Surat Kepala Badan Kepegawaian Negara Nomor : D.26-30/V.79-5/99 Tanggal 14 Juli 2017 Perihal Penetapan Kenaikan Pengkat dan Pensiun Pegawai Negeri Sipil setelah diundangkannya Peraturan Pemerintah Nomor 11 Tahun 2017 sangat dijelaskan bahwa pelaksanaan KPO dan PPO berbasis less paper di seluruh instansi dilaksanakan mulai tanggal 1 Oktober 2017 dan paling lambat 1 April 2018. Tidak semua jenis pemberhentian Pegawai Negeri Sipil berhak untuk mendapatkan jaminan pensiun dan jaminan hari tua, sedangkan semua PNS yang menerima pensiun adalah otomatis statusnya telah tidak lagi/diberhentikan sebagai Pegawai Negeri Sipil. Bahwa yang memperoleh hak kepegawaian berupa jaminan pensiun dan jaminan hari tua adalah pegawai yang saat pemberhentiannya dengan syarat diberhentikan dengan hormat sementara hal ini tidak berlaku bagi Pegawai Negeri Sipil yang diberhentikan dengan tidak hormat. Dapat dipahami pelaksanaan pemrosesan pensiun terbagi menjadi 2 (dua) berdasarkan tata cara pengusulannya yakni Pengusulan Pensiun melalui SAPK Manual dan Pengusulan Pensiun SAPK berbasis Less Paper. Yang dimaksud dari Pengusulan Pensiun melalui SAPK Manual adalah keseluruhan jenis pensiun dalam golongan ruang IV/b keatas maupun IV/b kebawah selain dari jenis Batas Usia Pensiun IV/b ke bawah. Sedangkan Pengusulan Pensiun SAPK berbasis Less Paper adalah usulan pensiun bagi Pegawai Negeri Sipil dengan Golongan Ruang IV/b ke bawah dengan status mencapai Batas Usia Pensiun.

Dengan melihat Pasal 305 Peraturan Pemerintah Nomor 11 Tahun 2017 terdapat 6 jenis pada masing-masing usulan yang disesuaikan dengan jenis golongan/ruang. Dapat dipahami bahwa Pengusulan Pensiun melalui SAPK Manual berjumlah 11 jenis yakni terdiri dari 6 jenis Golongan Ruang IV/b keatas ditambah dengan 5 jenis golongan ruang IV/b ke bawah (kecuali BUP IV/b ke bawah). Sedangkan Pengusulan Pensiun SAPK berbasis Less Paper hanya 1 (satu) yakni jenis usulan pensiun dengan BUP golongan ruang IV/b kebawah. Pemisahan SOP berdasarkan jenisnya menurut peneliti sangat diperlukan dikarenakan, Pertama, pengusulan pensiun yang berbeda dari Badan Kepegawaian Daerah ke Badan Kepegawaian Negara. Untuk kasus pensiun golongan ruang IV/b ke atas diusulkan ke BKN RI yang berada di Jakarta sedangkan golongan ruang IV/b ke bawah hanya diusulkan melalui wilayah kerja BKN Kantor Regional, dimana untuk Pemerintah Provini Sulawesi Utara diusulkan ke Kantor Regional XI BKN di Mapanget, Kota Manado. Kedua, pembagian skema SOP yang jelas dan mengacu pada aturan yang ada tentunya akan memudahkan urusan dari pengusul pensiun PNS. Ketiga, SOP yang jelas tidak menimbulkan tumpang tindih (over lapping) tugas dalam pelaksanaan di 
lapangan sehingga memudahkan pula penyelesaian tugas dan tanggungjawab pelaksana teknis Sub Bidang Pensiun PNS dan Pejabat Negara. Keadaan jenis SOP pensiun seharusnya disesuaikan jumlahnya berdasarkan dengan tata cara pengusulannya yakni 12 (dua belas) jenis. Hingga saat ini, Standar Operasional Prosedur Pelaksanaan Penetapan Pensiun Otomatis berbasis Less Paper juga belum ada pada Badan Kepegawaian Daerah Provinsi Sulawesi Utara selaku instansi yang melayani pengurusan pensiun dimana pelaksanaannya seharusnya sudah berjalan sejak surat Kepala BKN tentang pelaksanaan PPO diedarkan dan berlaku sejak 1 April 2018.

Pelaksanaan Penetapan Pensiun bagi PNS di lingkungan Pemerintah Provinsi Sulawesi Utara Golongan VI/b ke bawah dan Golong VI/b ke atas yang telah diselesaikan oleh Sub Bidang Pensiun PNS dan Pejabat Negara pada Badan Kepegawaian Daerah Provinsi Sulawesi Utara rentang waktu tahun 2014-2019 adalah sebagai berikut.

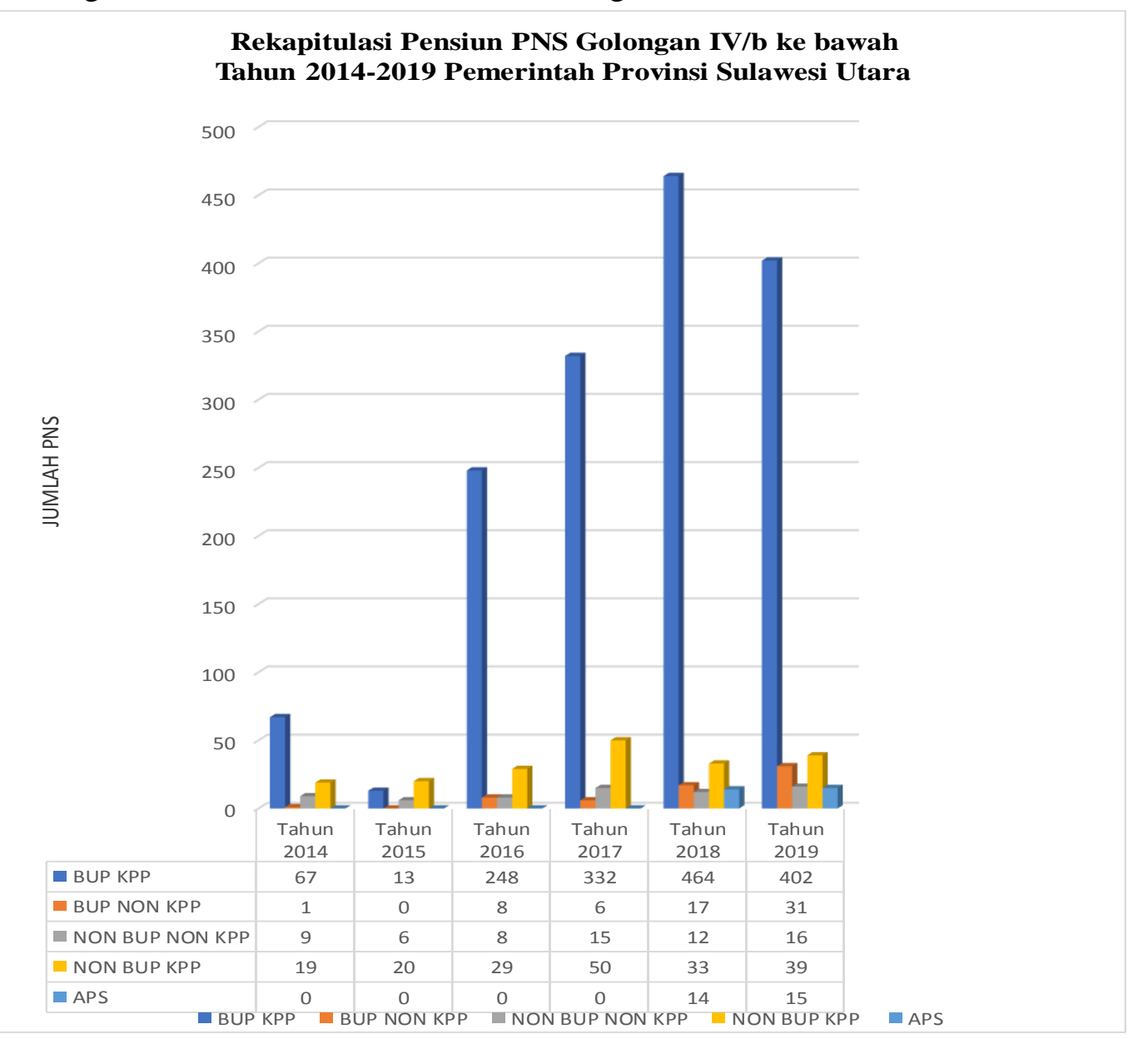

Sumber: Sistem Aplikasi Pelayanan Kepegawaian (SAPK) BKN keadaan tanggal 19 Juli 2020 


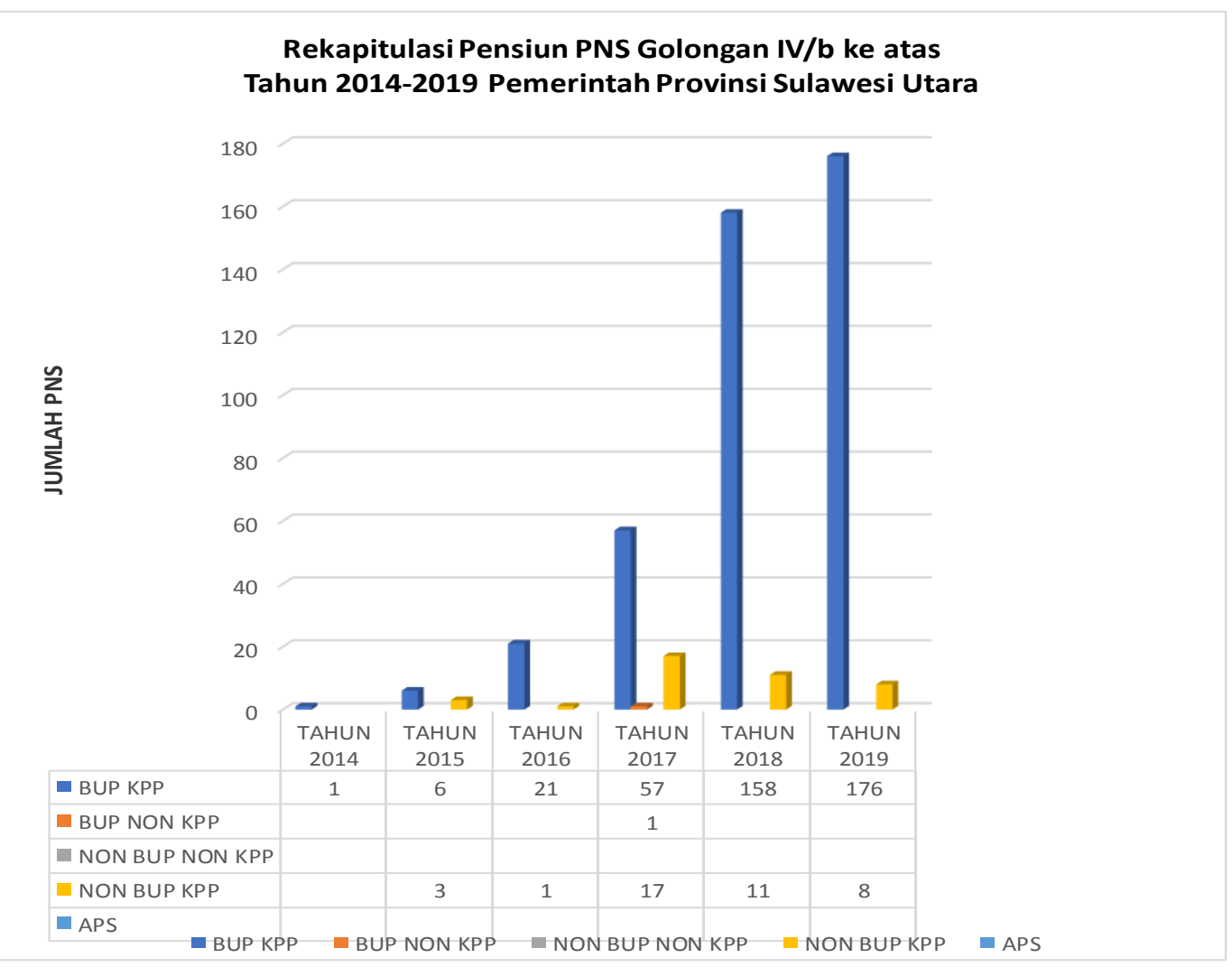

Sumber: Sistem Aplikasi Pelayanan Kepegawaian (SAPK) BKN keadaan tanggal 19 Juli 2020

Dari data realisasi pelayanan pensiun yang dilaksanakan pada Badan Kepegawaian Daerah Provinsi Sulawesi Utara terlihat bahwa sudah berjalan di Pemerintah Provinsi Sulawesi Utara dengan data pergolongan ruang. Kemampuan untuk memberikan pelayanan yang cepat (responsive) dan tepat kepada PNS yang akan mengurus pensiun secara otomatis. Dimana respon tersebut harus, tentunya harus cepat, tepat dan sesuai dengan ketentuan yang berlaku. Hal ini diawali mulai dari tingkat kedisiplinan yang baik dari pelaksana teknis Sub Bidang Pensiun PNS dan Pejabat Negara pada BKD Provinsi Sulawesi Utara sehingga selalu hadir dan menemukan solusi pada setiap permasalahan dan penyelesaian pengurusan pensiun. Pegawai Negeri Sipil diberikan keleluasaan untuk dapat menyampaikan setiap aspirasi, keluhan, kritik maupun saran terhadap pelayanan pensiun otomatis berbasis less paper.

Respon atau tanggap dalam menyelesaikan masalah terkait pelaksanaan tugas dapat terlihat dari tanggung jawab yang diemban, respon dalam pelaksanaan tugas oleh pelaksana teknis Sub Bidang Pensiun PNS dan Pejabat Negara pada BKD Provinsi Sulawesi Utara belum terlihat baik, tercatat berdasarkan data yang peniliti peroleh dari rekapan data Kantor Regional XI BKN. Hal ini diperkuat dengan data yang mana sejak tahun 2017 sampai dengan tahun 2020 terdapat 337 berkas usul pensiun untuk golongan IV/b ke bawah (PPO berbasis less paper) yang dikembalikan dari Kantor Regional XI BKN kepada Pemerintah Provinsi Sulawesi Utara karena tidak lengkap.

Respon pemecahan masalah dapat dilihat dari 2 (dua) aspek. Yang pertama, dari aspek pelayanan, respon pegawai (pelaksana teknis pemrosesan pensiun) saat terjadinya pengembalian berkas yang tidak lengkap, pelaksana teknis tidak langsung menghubungi PNS pengusul dan dapat disimpulkan bahwa dalam proses pengusulan ke Kantor Regional XI BKN masih banyak terdapat ketidaklengkapan berkas. Respon yang lambat dan membutuhkan waktu berhari-hari bahkan berminggu-minggu untuk dapat mengirim kembali kekurangan berkas ke Kanreg XI BKN dan tentunya proses ini memakan waktu yang lama karena prosedur kembali lagi dari awal Ketika usulan pertama kali diusulkan. Seharusnya sebelum diusulkan 
ke Kantor Regional XI BKN, berkas usulan pensiun di verifikasi terlebih dahulu dan dikirimkan sesuai dengan ketentuan persyaratan administrasi.

Kedua, dari aspek pemecahan masalah, secara garis besar terdapat dua permasalahan yang ada pada pemrosesan pensiun berbasis less paper, yakni kurangnya pegawai, fasilitas, dan adanya keperluan lain, sehingga penyelesaian kadang tidak fokus sementara pelayanan pensiun harus penuh dengan ketelitian yang apabila terdapat kesalahan akan berakibat fatal pada penetapan pensiun nantinya yang dapat membuat keterlambatan terbitnya Surat Keputusan Pensiun bahkan mengulang kembali prosedur dari awal pengusulan pensiun. Hingga saat ini, jumlah pelaksana teknis Sub Bidang Pensiun PNS dan Pejabat Negara belum bertambah sehingga berpengaruh pada kualitas dan kuantitas pemrosesan pensiun otomatis berbasis less paper.

Kemudian permasalahan lainnya yang kerap muncul adalah Kesalahan Nama dan NIP, sehingga tidak dapat terinputnya data pengusul pada Sistem Aplikasi Pelayanan Kepegawaian. Ini terjadi akibat tidak adanya rekonsiliasi data kepegawaian yang baik pada Sistem Kepegawaian (SIMPEG) yang dimiliki oleh BKD Provinsi Sulawesi Utara dengan data pada Sistem Aplikasi Pelayanan Kepegawaian (SAPK) oleh Badan Kepegawaian Negara.

Rata-rata penyelesaian kasus kesalahan Nama dan NIP pada SAPK bisa selesai 6 bulan lamanya. Ditambah lagi suasana pandemi Covid-19 yang mana untuk penugasan ke luar daerah menjadi berkurang sehingga akan berpengaruh terdapat waktu terbitnya Surat Keputusan Pensiun dengan resiko terbesar adalah putusnya gaji pokok PNS tanpa terbayarkannya Gaji Pokok Pensiun dikarenakan menunggu SK Pensiun yang terbit.

Berdasarkan data dan hasil wawancara dapat disimpulkan bahwa respon dalam pemecahan masalah belum maksimal, sehingga harus ada perbaikan dari dua tingkatan yakni pembuat aturan dan pelaksana aturan.

Berdasarkan pengamatan peneliti selama melaksanakan penelitian di lapangan tidak ada pengaduan terkait dengan sikap pelaksana teknis Sub Bidang Pensiun PNS dan Pejabat Negara pada BKD Provinsi Sulawesi Utara. Hal ini dapat dilihat dengan Kotak saran yang tidak terisi yang berada pada Front Office. Berdasarkan hasil wawancara ditemui beberapa keluhan dimana pelayanan pensiun otomatis, tetapi pelaksanaanya tidak otomatis. Pengusul harus bolak balik untuk mengecek terbitnya SK pensiun. Dan juga tidak adanya kepastian waktu kapan SK Pensiun akan selesai sehingga harus berulang kali kembali mengecek ke Badan Kepegawaian Daerah Provinsi Sulawesi Utara.

Inovasi menjadi salah satu upaya bagi instansi pemerintah untuk terus meningkatkan kualitas pelayanan. Inovasi pelayanan terbagi menjadi dua yakni upaya instansi pemerintah berinovasi untuk memanfaatkan potensi yang dimiliki, dan inovasi untuk mengatasi masalah yang ada. Pertama, inovasi untuk memanfaatkan potensi yang dimiliki yakni berdasarkan pengamatan peneliti selama melakukan penelitian, Pelaksanaan Penetapan Pensiun Otomatis berbasis Less Paper dilayani di ruangan Front Office BKD Provinsi Sulawesi Utara oleh pelaksana teknis sesuai kebutuhan pegawai yang datang. Petugas Front Office BKD Provinsi Sulawesi Utara yang siap sedia adalah 1 (satu) pelaksana teknis yang bertugas menangani surat masuk dan keluar serta 1 (satu) Satuan Polisi Pamong Praja yang ditugaskan untuk pengamanan di perangkat daerah. Dalam hal keamanan di Front Office cukup baik namun dari segi kenyamanan belum maksimal dikarenakan tidak adanya sekat pemisah sehingga setiap kebutuhan layanan kepegawaian menjadi satu di satu ruangan. Hal ini tentunya menimbulkan suara yang cukup bising dan beresiko apabila terdapat kebutuhuan pelayanan ke BKD Provinsi Sulawesi Utara yang bersifat rahasia. Kedua, inovasi untuk mengatasi masalah yang ada, dalam hal ini BKD ProvinsiSulawesi Utara memiliki inovasi-inovasi dalam memudahkan layanan kepegawaian yakni sebagai berikut:

a. Sistem Informasi Manajemen Kepegawaian (SIMPEG);

b. Face Recognition (Absensi dengan deteksi wajah); 
c. Simvoni (Sistem Verifikasi Online);

d. E-Jabatan Fungsional (E-Jaf);

e. Sistem Informasi Manajemen THL (SIM ON THL);

f. Sistem Informasi Manajemen Kepangkatan Elektronik (SIMPATI).

Namun dalam Pelaksanaan Penetapan Pensiun Otomatis berbasis Less Paper belum ada inovasi dari BKD Provinsi Sulawesi Utara. Dapat disimpulkan bahwa belum adanya inovasi layanan dari BKD Provinsi Sulawesi Utara terkait pemrosesan pensiun otomatis berbasis less paper. Jika kita melihat pentingnya poin dari huruf $\mathrm{k}$ dan 1 dari Manajemen PNS yang meliputi: a. penyusunan dan penetapan kebutuhan; b. pengadaan; c. pangkat dan Jabatan; d. pengembangan karier; e. pola karier; f. promosi; g. mutasi; h. penilaian kinerja; i. penggajian dan tunjangan; i. penghargaan; j. disiplin; k. pemberhentian; 1 . jaminan pensiun dan jaminan hari tua; dan n. perlindungan, seyogyanya layanan kepegawaian terkait pensiun menjadi salah satu prioritas primer. Begitu pula dengan pengadaan inovasi dari instansi pemerintah daerah. Terlebih lagi, urusan pensiun telah menyesuaikan dengan perkembangan era digital dimana sudah berbasis less paper. Menilik kembali berdasarkan Surat Kepala Badan Kepegawaian Negara Nomor: D.26-30/V.79-5/99 Tanggal 14 Juli 2017 Perihal Penetapan Kenaikan Pengkat dan Pensiun Pegawai Negeri Sipil setelah diundangkannya Peraturan Pemerintah Nomor 11 Tahun 2017 yang mewajibkan KPO dan PPO berbasis less paper dilaksanakan secara bersamaan oleh pemerintah daerah. Namun pada pelaksanaanya di Provinsi Sulawesi Utara, kemudahan verifikasi berkas berupa inovasi layanan hanya difokuskan pada pengurusan Kenaikan Pangkat Otomatis dengan adanya Sistem Informasi Manajemen Kepangkatan Elektronik (SIMPATI) sedangkan pengurusan pensiun yang lebih kompleks permasalahannya sejauh ini belum memiliki inovasi sama sekali.

Sejauh mana Pemerintah Provinsi Sulawesi Utara melalui BKD Provinsi Sulawesi Utara memberikan rasa aman dan nyaman bagi Pegawai Negeri Sipil yang akan mengusulkan proses pensiun otomatis berbasis less paper, hal ini dapat dilihat sejauh mana sosialisasi kepada PNS Golongan Ruang IV/b kebawah yang akan memasuki Batas Usia Pensiun dilaksanakan di lingkungan Pemerintah Provinsi Sulawesi Utara. Sehingga sasaran layanan pensiun otomatis mengetahui program pemerintah, kemudahan dan kepastian akan setiap informasi yang telah dilaksanakan.

Transparansi pelaksananaan Penetapan Pensiun Otomatis berbasis Less Paper merupakan bentuk dari keterbukaan informasi oleh intansi pemerintah dalam hal ini Badan Kepegawaian Daerah Provinsi Sulawesi Utara kepada PNS yang akan mengusulkan jenis pensiun less paper. Berkaitan dengan penerapan dan pelaksanaan keterbukaan informasi publik sesuai amanah Undang-Undang Nomor 14 tahun 2008 tentang Keterbukaan Informasi Publik (UU KIP). Tujuannya adalah membentuk budaya dalam mewujudkan penyelenggaraan pemerintahan yang baik dan bersih.

Pada pelaksanaan Penetapan Pensiun Otomatis berbasis Less Paper belum begitu melaksanakan transparansi informasi publik hal ini dapat dilihat dari tidak adanya informasi yang dapat di akses melalui digitalisasi. Website BKD Provinsi Sulawesi Utara belum menyajikan informasi layanan pensiun otomatis berbasis less paper. Sampai saat ini informasi pensiun belum terupdate pada Website BKD dikarenakan dari Sub Bidang Pensiun PNS dan Pejabat Negara tidak menginformasikan substansi pelayanan pensiun otomatis berbasis less paper itu sendiri. Hanya terdapat berita atau informasi terkini dalam Website yang terjadi pada Badan Kepegawaian Daerah Provinsi Sulawesi Utara, untuk terkait masalah yang lebih teknis harus berkoordinasi langsung dengan bidang yang menangani teknis permasalahan. Permasalahan lainnya, BKD Provinsi Sulawesi Utara belum memiliki teknologi yang dapat memonitor atau di akses terkait setiap tahapan dari proses penetapan pensiun otomatis berbasis less paper sejak berkas diusulkan oleh perangkat daerah hingga terbitnya Surat Keputusan Pensiun serta informasi jika terdapat kelengkapan berkas yang masih kurang. 
Timbulnya persepsi dari PNS yang akan memasuki usia pensiun terkait dengan kata "Otomatis" yang pada faktanya masih membutuhkan kelengkapan berkas aaministrasi yang banyak. BKD Provinsi Sulawesi Utara telah melakukan upaya untuk mengatasi permasalahan ini dengan rutin melaksanan kegiatan setiap tahunnya berupa sosialisasi atau pembekalan terkait PPO berbasis Less Paper yang ditujukan bagi PNS yang akan memasuki usia pensiun 1 tahun sebelumnya. Akan tetapi kegiatan dimaksud hanya dapat diterapkan ke beberapa PNS tetapi tidak untuk beberapa PNS lainnya karena terkendala pada waktu sosialisasi yang mana sebagian PNS tidak bisa hadir khususnya bagi PNS Fungsional Tenaga Pendidik. Inilah yang menyebabkan kesamaan persepsi tentang PPO ini tidak berjalan dengan optimal.

Tolok ukur dari kemampuan Pemerintah Provinsi Sulawesi Utara melalui BKD Provinsi Sulawesi Utara menunjukkan keberadaan dan eksistensinya dalam pelaksanaan penetapan pensiun berbasis less paper. Hal ini dapat dilihat dari Struktur Layanan atau SOP, sumber daya manusia yang ada, sarana prasarana penunjang. Secara singkat dapat diartikan sebagai penampilan fisik, peralatan, personil dan materi komunikasi.

Pemerintah Provinsi Sulawesi Utara memiliki struktur organisasi yang kuat sehingga hal menjadi faktor pendukung pelaksanaan penetapan pensiun berbasis less paper. Beberapa perangkat daerah maupun instansi terkait yang memiliki peran penting dalam pelaksanaan pensiun bagi PNS Golongan Ruang IV/b kebawah adalah sebagai berikut:

a. Badan Kepegawaian Daerah Provinsi Sulawesi Utara (pemroses penetapan pensiun berbasis less paper);

b. Badan Keuangan dan Aset Daerah (koordinasi penggajian pensiun);

c. PT. Taspen Persero (Badan Usaha Milik Negara Indonesia yang bergerak di bidang asuransi tabungan hari tua dan dana pensiun bagi ASN dan Pejabat Negara);

d. Kantor Regional XI Badan Kepegawaian Negara (lembaga pemerintah non kementerian yang diberi kewenangan melakukan pembinaan dan menyelenggarakan manajemen ASN secara nasional);

e. Seluruh perangkat daerah yang ada di lingkungan Pemerintah Provinsi Sulawesi Utara (sebagai oerangkat daerah pengusul).

Suatu organisasi yang baik membutuhkan sumber daya manusia yang sesuai dengan kebutuhan organisasi. Badan Kepegawaian Daerah provinsi Sulawesi Utara memiliki sumber daya yang memadai dan berkualitas. Hal ini dapat dilihat pada tabel dibawah ini:

Tabel 1 Rekapitulasi PNS Berdasarkan Usia pada Badan Kepegawaian Daerah Provinsi Sulawesi Utara

\begin{tabular}{|c|c|c|}
\hline No. & Antara Usia & Jumlah (orang) \\
\hline$(1)$ & $(2)$ & $(3)$ \\
\hline 1 & Kurang dari 26 tahun & 2 \\
\hline 2 & Antara 26 s.d 30 tahun & 15 \\
\hline 3 & Antara 31 s.d 35 tahun & 14 \\
\hline 4 & Antara 36 s.d 40 tahun & 7 \\
\hline 5 & Antara 41 s.d 45 tahun & 4 \\
\hline 6 & Antara 46 s.d 50 tahun & 5 \\
\hline 7 & Antara 51 s.d 55 tahun & 0 \\
\hline 8 & Lebih dari 55 tahun & 77 \\
\hline
\end{tabular}

Sumber: bkdsulutprov.go.id

Berdasarkan tabel diatas dapat dilihat bahwa jumlah pegawai pada usia yang produktif lebih banyak daripada yang non produktif. Sedangkan pemrosesan pensiun bagi Pegawai Negeri Sipil di lingkungan Pemerintah Provinsi Sulawesi Utara dikelola oleh Bidang Mutasi dan Status Kepegawaian sedangkan teknis pemrosesan pensiun berada pada Sub Bidang Pensiun PNS dan Pejabat Negara. Adapun Pegawai (personil) yang menangani Pensiun PNS 
yaitu pada Sub bidang Pensiun PNS dan Pejabat Negara pada BKD Provinsi Sulawesi Utara ditunjukkan dalam tabel berikut:

Tabel 2 PNS Sub Bidang Pensiun Pegawai Negeri Sipil dan Pejabat Negara pada Badan Kepegawaian Daerah Provinsi Sulawesi Utara Tahun 2020

\begin{tabular}{|l|l|c|c|c|}
\hline \multicolumn{1}{|c|}{ Jabatan } & \multicolumn{1}{|c|}{ Nama } & Gol & Pendidikan & \multicolumn{1}{c|}{ Riwayat Diklat } \\
\hline $\begin{array}{l}\text { Kasubbid } \\
\text { Pensiun PNS } \\
\text { dan Pejabat } \\
\text { Negara }\end{array}$ & $\begin{array}{l}\text { Denny Hendrik Lumintang, S.Sos } \\
\text { NIP. 197405041997031009 }\end{array}$ & & S1 & Diklat Prajabatan Gol. II \\
\hline Pelaksana & $\begin{array}{l}\text { I. Irene Sompotan, SE } \\
\text { NIP. 198209222010012007 }\end{array}$ & III/c & S1 & Diklat Prajabatan \\
\cline { 2 - 6 } & 2. Gersom Kawatu & II/b & SMA & $\begin{array}{l}\text { Diklat Prajabatan } \\
\text { Pelatihan TIK-Kelas } \\
\text { Nemrogaman Web (oleh } \\
\text { Unika De La Salle } \\
\text { Manado) }\end{array}$ \\
\hline
\end{tabular}

Berdasarkan data diatas Pegawai (personil) yang menangani Pensiun PNS pada Sub Bidang Pensiun PNS dan Pejabat Negara pada BKD Provinsi Sulawesi Utara hanya berjumlah 3 orang pegawai. Berdasarkan data jumlah pegawai di sub bidang Pensiun PNS dan Pejabat Negara tersebut sangat kurang apabila dibandingkan dengan jumlah pegawai di lingkungan Pemerintah Provinsi Sulawesi Utara yang akan di proses usulan pensiunnya.

Sarana dan prasaran fisik merupakan alat pendukung yang sangat dibutuhkan, kekurangan sarana prasarana akan berdampak pada ketidakmaksimalan pencapaian suatu kebijakan. Sarana prasarana yang ada pada Badan Kepegawaian Daerah Provinsi Sulawesi Utara guna pelaksanaan penetapan pensiun otomatis berbasis less paper khususnya pada Sub Bidang Pensiun PNS dan Pejabat Negara adalah berupa 3 Perangkat Komputer, 2 printer, 1 mesin TIK. Hal ini dinilai belum bisa mengimbangi kebutuhan pemrosesan pensiun, terlebih mulai dari pengusulan, surat menyurat terkait pensiun, hingga terbitnya Surat Keputusan Pensiun dilakukan oleh Sub Bidang Pensiun PNS dan Pejabat Negara.

Adanya perhatian yang tulus diberikan bagi PNS yang akan mengusulkan proses pensiun otomatis berbasis less paper dengan berupaya memberikan pengertian, pengetahuan, dan pelayanan yang optimal. Secara singkat dapat diartikan sebagai sikap dan perilaku dalam menyelenggarakan pelayanan pensiun otomatis berbasis less paper.

Berdasarkan hasil pengamatan pada pegawai di BKD Provinsi Sulawesi Utara, tingkat loyalitas dan kepatuhan terhadap aturan cukup terlihat baik, pegawai melaksanakan tugas dengan baik dan mengikuti sesuai arahan pimpinan, dimana apa yang diperintahkan oleh Pimpinan dilaksanakan sesuai arahan selama tidak bertentangan dengan aturan dan ketentuan yang berlaku. Hingga saat ini keahlian Pegawai yang ada pada BKD Provinsi Sulawesi Utara hanya berada pada ranah admnistrasi perkantoran. Pegawai BKD Provinsi Sulawesi Utara tidak memiliki kemampuan teknis dalam melakukan survey lapangan.

Ditinjau dari aspek Pendidikan, keahlian pegawai BKD Provinsi Sulawesi Utara di dominasi oleh Sarjana dan Magister. Sedangkan yang lainnya berpendidikan D3 komputer. Untuk keahlian pada Sub Bidang Pensiun dan Pejabat Negara belum ada pelaksana teknis dengan tingkat Pendidikan keahlian di bidang computer, seharusnya hal ini menjadi perhatian dikarenakan tugas pelaksana teknis yang langsung berhubungan dengan Sistem Pelayanan Aplikasi Kepegawaian dimana perlunya keahlian dalam memaintenance dan mengoperasikan fitur Penetapan Pensiun Otomatis berbasis less paper.

Dilihat dari hasil pengamatan, bahwa tingkat disiplin pegawai dalam rangka kehadiran sudah cukup baik terlebih khusus di masa pandemi Covid-19 saat ini. dengan kondisi keterbatasan ini perangkat daerah Pemprov Sulut memanfaatkan teknologi. Pemerintah Provinsi Sulawesi Utara menerapkan kehadiran fisik 25 persen bagi PNS dan THL di kantor 
dan sisanya bekerja dari rumah. Pemerintah Provinsi Sulawesi Utara mendorong agar bisa mewujudkan sistem yang jauh lebih efisien ketimbang cara konvensional.

\section{KESIMPULAN}

Kualitas pelayanan penetapan pensiun otomatis berbasis less paper bagi Pegawai Negeri Sipil di lingkungan Pemerintah Provinsi Sulawesi Utara belum berjalan dengan optimal karena belum terpenuhinya semua kriteria untuk mengukur Kualitas Pelayanan yaitu Reliability, dimana belum diterapkannya Standar Operasional Prosedur yang berpedoman pada Standar Operasional Prosedur Penetapan Pensiun Otomatis Berbasis Less Paper. Responsivnees, dimana belum adanya mekanisme terkait penyelesaian masalah yang sering timbul dalam pemrosesan pensiun serta belum jelasnya penyelesaian waktu terbitnya Surat Keputusan Pensiun serta lambatnya penanganan permasalahan pensiun. Selain itu bahwa belum adanya inovasi elektronik layanan dari BKD Provinsi Sulawesi Utara terkait pemrosesan pensiun otomatis berbasis Less Paper. Assurance dimana belum adanya transparansi pelaksanaan penetapan pensiun berbasis Less Paper ditandai dengan tidak adanya informasi yang mumpuni pada website BKD Provinsi Sulawesi Utara dan tidak adanya akses online terkait pelayanan pensiun otomatis berbasis Less Paper. Serta sosialisasi mengenai pelaksanaan PPO Less Paper belum sepenuhnya dipahami oleh PNS yang akan memasuki Batas Usia Pensiun terlebih khusus bagi Tenaga Pendidik. Tangible terkait dengan kurangnya personil pelaksana teknis pada Sub Bidang Pensiun PNS dan Pejabat Negara. Emphaty, dimana kurangnya pengetahuan dari pelaksana teknis dalam menguasai penggunaan Sistem Aplikasi Pelayanan Kepegawaian (SAPK) dengan fitur Pelayanan Pensiun Otomatis berbasis Less Paper.

\section{DAFTAR PUSTAKA}

Parasuraman, A. (2014). The Behaviorial Consequenses of Service Quality. New Jersey: Prentince Hall.

Abidin, S. Z. (2016). Kebijakan Publik. Jakarta: Salemba Humanika.

Afifuddin. (2009). Metodologi Penelitian Kualitatif. Bandung: Pustaka Setia.

Afifuddin, \& Saebani, B. A. (2009). Metodologi Penelitian Kualitatif. Bandung: Pustaka Setia.

Agustino, L. (2017). Dasar-Dasar Kebijakan Publik. Bandung: Alfabeta.

Arifin, J., \& Fauzi, A. (2007). Aplikasi Excel Dalam Aspek Kuantitatif Manajemen Sumber Daya Manusia. Jakarta: Alex Media Komputindo.

Arikunto, S. (2010). Metode Penelitian Kualitatif. Jakarta: Bumi Aksara.

Arikunto, S. (2010). Prosedur Penelitian Suatu Pendekatan Praktik. Jakarta: Rineka Cipta.

Gulo, W. (2007). Metodologi Penelitian. Jakarta: Grasindo: Jakarta.

Hasibuan, M. S. P. (2016). Manajemen Sumber Daya Manusia. Jakarta: Bumi Aksara.

Herman, S. (2008). Manajemen Sumber Daya Manusia. Yogyakarta: Graha Ilmu.

Peraturan Pemerintah Republik Indonesia Nomor 32 Tahun 1979 Tentang Pemberhentian Pegawai Negeri Sipil

Peraturan Pemerintah Republik Indonesia Nomor 1 Tahun 1994 Tentang Perubahan Atas Peraturan Pemerintah Nomor 32 Tahun 1979 Tentang Pemberhentian Pegawai Negeri Sipil

Peraturan Pemerintah Republik Indonesia Nomor 11 Tahun 2017 tentang Manajemen Pegawai Negeri Sipil

Peraturan BKN Nomor 26 Tahun 2013 tentang Pedoman Pemberhentian dan Pemberian Pensiun Pegawai Negeri Sipil Yang Mencapai Batas Usia Pensiun Yang Akan Diberhentikan Dalam Pangkat Pembina Tingkat I Golongan Ruang IV/b Ke Bawah. 
Peraturan BKN No. 2 Tahun 2018 tentang Pedoman Pemberian Pertimbangan Teknis Pensiun PNS dan Pensiun Janda/Duda PNS.

Surat Kepala Badan Kepegawaian Negara Republik Indonesia No. K.26-30/V.7-3/99 tentang Batas Usia Pensiun PNS.

Surat Kepala Badan Kepegawaian Negara Republik Indonesia Nomor: D.26-30/V.79-5/99

Tanggal 14 Juli 2017 Perihal Penetapan Kenaikan Pengkat dan Pensiun Pegawai Negeri Sipil setelah diundangkannya Peraturan Pemerintah Nomor 11 Tahun 2017.

Undang-Undang Republik Indonesia Nomor 11 Tahun 1969 tentang Pensiun Pegawai Dan Pensiun-Janda/Duda Pegawai.

Undang-Undang Republik Indonesia Nomor 5 Tahun 2014 tentang Aparatur Sipil Negara. 